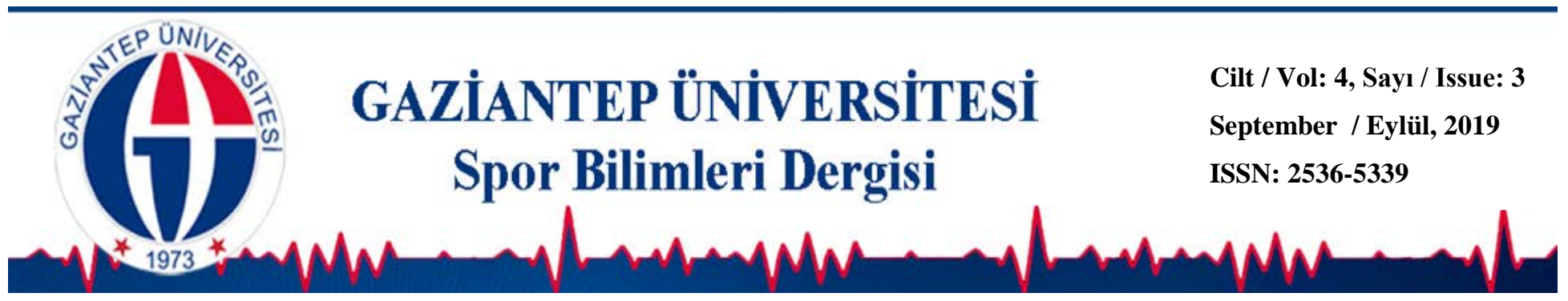

\title{
Türkiye'nin Olimpiyat Adaylıkları Üzerine Nitel Bir Araştırma
}

\author{
Sait TARAKÇIOĞLU ${ }^{1 *}$ (D) \\ Safter ELMAS ${ }^{2}$ iD \\ ${ }^{1}$ Ege Üniversitesi, Spor Bilimleri Fakültesi, IZZMIR \\ ${ }^{2}$ Marmara Üniversitesi, Spor Bilimleri Fakültesi, ISTANBUL
}

DOI: $10.31680 /$ gaunjss.583505

Orijinal Makale / Original Article

Geliş Tarihi / Received: 27.06.2019

Kabul Tarihi / Accepted: 28.08.2019

Yayın Tarihi / Published: 22.09.2019

Öz

Türkiye, İstanbul şehri ile yaz olimpiyatlarına ev sahipliği yapmak için beş kez aday oldu ve hiç kazanamadı. Bu araştırmanın amacı, Türkiye'nin yaz olimpiyat oyunlarına ev sahipliği yapamamasının nedenlerini ve buna yönelik çözüm önerilerini uzman görüşleri ışığında ortaya koymaktır. Araştırmada, nitel araştırmalardan görüşme yöntemi kullanılmıştır. Öncelikle, olimpiyatlar konusunda uzman olduğu düşünülen on üç kişi amaçlı örneklem yöntemiyle seçilmiştir. Konuyla ilgili ayrıntılı bir literatür taramasının ardından görüşmelerde kullanılacak sorular yarı yapılandırılmış olarak hazırlanmıştır. Türkiye'nin yaz olimpiyatlarına ev sahipliği yapamamasının nedenleri ve çözüm önerileri ile ilgili olan sorular birebir ve yüz yüze yapılan görüşmelerde uzmanlara yöneltilmiştir. Katılımcıların onayı alınarak elektronik ortama kaydedilen bu görüşmeler Ağustos 2018 ve Nisan 2019 arasında, İzmir ve İstanbul'da gerçekleştirilmiştir. Görüşmelerden elde edilen veriler tanımlayıcı içerik analizine tabi tutulmuştur. Görüşmelerden elde edilen verilerden, spordaki başarısızlık, sporun topluma yayılmaması, doping, siyasi ortam, yanlış şehir seçimi, tesis ve altyapı eksikliği, ülkedeki ekonomik durum ve ülkenin tanıtım eksikliği Türkiye'nin olimpiyatları alamamasının önündeki engeller olarak görülmektedir. Bu engellerin ortadan kaldırılmasına yönelik öneriler ise; sporun topluma yayılması, devlet kurumlarının daha etkin olması, dopingin ülke sporundan silinmesi, merkezi bir spor sisteminin kurulması ve bu sistem içinde liyakate önem verilmesi olarak sıralanmaktadır. Sonuç olarak, olimpiyatlara ev sahipliği yapabilme yolunda Türkiye'nin atacağı uzun erimli adımların, ülkedeki spor kültürünün gelişimine katkıda bulunacağı ve uluslararası yarışmalarda ülkenin başarısını arttıracağı öngörülmektedir.

Anahtar Sözcükler: Türkiye, İstanbul, yaz olimpiyatları, olimpiyat adaylığı

\section{A Qualitative Research on Turkey's Bids for the Olympic Games}

\begin{abstract}
Turkey has been candidate for hosting the Summer Olympic Games five times with its bidding city Istanbul, but it has never won the election. This qualitative research investigates the reasons of Turkey's failure in attempts to host the Games, and solution offers for the possible future biddings in accordance with the views of experts. A purposeful sampling technique was used to identify the thirteen experts that were asked to be interviewed for the research. After a comprehensive literature review, the semi-structured questions were prepared for the interviews. The three questions were about the reasons of Turkey's failure in attempts to host the Games and solution offers for the possible future biddings. The individual interviews were carried out between August of 2018 and April of 2019 in İzmir and İstanbul, and tape-recorded with the prior permission of the participants. The data obtained from the interviews was evaluated by a descriptive content analysis. From the obtained data, eight categories were identified about the reasons of Turkey's failure. These are; being an unsuccessful country in sports, not having a sports culture, doping prevalence, politics, wrong bidding city, lack of proper sporting facilities and infrastructure, economic status, and lack of promotion of the country. Likewise, the solution offers are; spread of sporting activities throughout the society, more active state constitutions, anti-doping struggle, and foundation of a central sports system and consideration of the officials' competency in this system. In conclusion, it is foreseen that the long-term plans will contribute to the improvement of the needed sports culture in Turkey and increase the success of the country in the international sports competitions along with the prospect bidding processes.
\end{abstract}

Keywords: Turkey, İstanbul, the Summer Olympic Games, Olympic bidding

\footnotetext{
* Sorumlu Yazar: Sait TARAKÇIOĞLU
}

E-mail: sait.tarakcioglu@gmail.com 


\section{Giriş}

Olimpiyat organizasyonları, modernleşmiş olduğu ilk günden günümüze uzanan tarihsel süreçte, hem ekonomik hem politik hem de kültürel özellikleri bakımından konjonktürel olarak önemini her daim korumaktadır. Olimpiyatlar, ulusdevletlerin gövde gösterisi yaptıkları en büyük sportif etkinlik alanı olmakla birlikte, ülkelerin ve şehirlerin imajına, ekonomisine, sosyal, mekânsal ve kültürel potansiyeline, turizm ve spor imkânlarına dair hem olumlu hem de olumsuz etkiler bırakmaktadır (Aslan, Ankaya ve Balık, 2019).

Neo-liberal ekonomik anlayışın 1980'lerin başı itibariyle dünyada eş zamanlı olarak güç kazanması, spor dünyasını da hızlıca çekim alanına sokmuş, dört yılda bir gerçekleşen olimpiyatlar ve futbol dünya kupası organizasyonlarının önemi, bu itibarla farklı bir boyut kazanmıştır. Özellikle, uluslararası devasa sportif etkinliklerin ev sahipliğini elde etmek demek, bir yanıyla ülkelerin ve kentlerin çevrelerini etkileyebilmek, tercih edilen olabilmek ve böylece küresel sermayeyi çekerek rakipleri arasında güçlü bir konuma gelebilmek için sürekli bir yarış içerisinde olması anlamına gelmektedir. Bu kapsamda, aday ülke ve şehirler tanıtım ve markalaşma faaliyetleri, medyada görünürlüklerini arttırma dolayısıyla ekonomik gelişimlerini yükseltebilmenin yollarını aramaktadır (Görkemli, Matır, Çelik ve Seki, 2014). Bu bağlamda, olimpiyatlar şehirlerin ev sahipliğini yapabilmek için yoğun çaba sarf ettiği, propagandalar geliştirerek yarıştığı en önemli etkinliklerdendir. Böylesi büyük etkinliklere ev sahipliği yaparak sosyal, kültürel, kentsel, siyasi ve ekonomik anlamda kazanımlar sağlamak, olumlu ve prestijli bir kent imajı oluşturmak ve böylece uluslararası arenada güç kazanarak boy göstermeye çalışmak çoğu aday ülkenin/şehrin hayali olarak karşımıza çıkmaktadır (Uysal, 2014).

1980 yılından itibaren sırayla bakıldığında Moskova, Los Angeles, Seul, Barselona, Atlanta, Sidney, Atina, Pekin, Londra, Rio de Janeiro ve son olarak 2020'de Tokyo olimpiyat oyunlarına son kırk yılda ev sahipliği yapmışlardır. Şehirlerin büyük kısmının ortak özellikleri (Atina ve Rio de Janeiro hariç), ekonomik gelişmişlik düzeylerinin oldukça güçlü olduğu şehirler olarak öne çıkmalarıdır (Liao ve Pitts, 2006). Olimpiyatlar, son çeyrek yüzyılda neo-liberal politikalara bağımlı olarak yeniden organize edilip dönüştürüldüğünden oldukça pahalı ve masraflı organizasyonlar olmaya başlamışlardır. Masrafların en büyük kısmının inşa edilen tesisler oluşturduğu için, bütçe planlaması yapılırken gelişmekte olan ülkelerin ev 
sahipliği için az olan şansları iyice erimektedir (Kavanoz, 2017; Liao ve Pitts, 2006). Çünkü oyunların yapılacağı ve sporcuların yarışacakları stadyumlar, salonlar, kent içindeki dağınık konumlan(ma)mış tesisler, spor alanları, olimpiyat köyleri ve her olimpiyatlarda artan katıımcı (sporcu, seyirci, basın çalışanları vb.) sayısı, olimpiyatların şimdiye kadar büyük bir çoğunlukla gelişmiş ülkelerde yapılmasına neden olmuştur ve olmaktadır (Feddersen, Maennig ve Zimmermann, 2008).

Olimpiyatların organizasyonunda ekonomik gelişmişlik kriterinin haricinde başka boyutlar da önem arz etmektedir. Değişik ülkelerden sporcular, delegasyonlar, yarışmalar, yönetim, planlama, pazarlama, risk, bütçeleme, tanıtım ve diğer faaliyetler bir organizasyonda yer alan ve eksiksiz bir şekilde tamamlanması gereken asli basamaklardır. Böylesine büyük spor organizasyonlarını alma ve yönetmenin çok boyutlu gereklilikleri, zorlukları ve süreçleri vardır. Mali planlamalar dikkatle oluşturulmalı, insan kaynağı iyi yönetilmeli, potansiyel risklere yönelik tespitler belirlenmeli, sonrasında önlemler alınmalı, sporcular ve seyirciler için sağlıklı, konforlu ve güvenli bir ortam yaratılmalı ve "pazar odaklı" bir yaklaşım ile seyirci/izleyici/tüketici beklentileri, güncel yönelimleri göz önünde bulundurulmalıdır (Leopkey ve Parent, 2009).

\section{Türkiye'nin/İstanbul'un Adaylık Süreçleri}

İstanbul, özellikle 2020 sürecine hazırlanırken coğrafik ve jeopolitik önemi çok olan Avrupa ve Asya kıtalarına sahip olma, buraları birbirine bağlayan köprüleri ve eşsiz güzellikteki boğazı gibi güçlendirici avantajları kullanarak stratejik bir hamle gerçekleştirmiştir. Coğrafik, jeolojik ve fiziki özellikleri olan bu avantajları, olimpiyatlarda en önemli hususlardan biri olan kültürel çeşitlilik anlamına dönüştürerek Bridge Together gibi bir motto ile başvuru yapmıştır. Bu motto aynı zamanda şehrin tarihini, dokusunu, mimarisini de yansıtmaktadır. Şehir çok farklı inanışlara, kimliklere ve toplumlara ev sahipliği yapmış; bugün bile farklılıklara dair miras korunabilmiş̧ir. Bu açıdan bakıldığında, birbirleriyle rekabet eden aday kentler içerisinde, İstanbul için öne çıkarılan bu özelliklerin ayırt edici bir kentsel strateji içerdiği; kentsel markayı ortaya koyabilmek için önemli ölçütlerden olan 'olumlu', 'ilgi çekici' ve 'heyecan uyandırıcı' nitelikleri sağladığı, kentin somut tarihi, kültürel ve mimari özelliklerini temsil eden, simgesel ve soyut değerler içeren özel olarak tasarlanmış bir sloganın kullanıldığı görülmektedir (Ashworth ve Kavaratzis, 2009; Zhang ve Zhao, 2009; Kavanoz, 2017). 
İstanbul'un son başvuru döneminde güçlü ve etkili bir başvuru mottosu ile işe koyulması önemli olmakla birlikte ev sahipliği hakkını elde etmede belirleyici çok daha farklı ve kritik gereklilikler mevcuttur. Uluslararası Olimpiyat Komitesi (IOC) tarafından belirlenen aday şehir dosya prosedürlerine bakıldığında, vizyon, miras ve iletişim; siyasi ve ekonomik iklim ve yapısı; gümrük ve göçmenlik işlemleri; çevre ve meteoroloji; finans; pazarlama; spor ve mekanları; paralimpik oyunlar; olimpik köy; sağlık servisleri ve doping kontrol; güvenlik; konaklama; ulaşım; teknoloji ve medya vb. on yedi farklı kriterin olduğu görülmektedir (Ünlü, 2015). İstanbul'un beş defa başvurup, son dönemde finallere kaldığı olimpiyat ev sahipliğine adaylık süreçlerinde yukarıdaki on yedi kriterin birçoğu ile ilgili zorluklar yaşadığını ve yaşamaya devam ettiğini söylemek mümkün.

Bu araştırma, yalnızca İstanbul'u değil, genel olarak Türkiye'yi bir ev sahibi ülke olarak ele alırken; yalnızca son adayığını değil, Türkiye'nin tüm adaylık süreçleriyle ilgili değerlendirmeleri kapsamaktadır.

\section{Yöntem}

Bu araştırma, Türkiye'nin yaz olimpiyat oyunlarına ev sahipliği yapamamasının nedenlerini ve çözüm önerilerini uzman görüşleri ışığında tartışmaktadır. Bu bağlamda, Türkiye'de dört yılda bir yoğun gündem oluşturan olimpiyatlar olgusunun çok boyutlu belirleyicilerini ortaya koymak amaçlanmıştır. Bu sebeple, bir fenomenin tüm boyutlarını derinlikli ve çeşitli bir yaklaşımla ele almayı amaçlayan fenomenolojik araştırma deseni tercih edilmiştir (Patton, 2002; Slater ve Tiggemann, 2010). Araştırmada, nitel araştırmalardan görüşme yöntemi kullanılmıştır. Öncelikle, olimpiyatlar konusunda uzman olduğu düşünülen on üç kişi amaçlı örneklem (Palinkas, Horwitz ve Green, 2015; Patton, 2002) yöntemiyle seçilmiştir. Amaçlı örneklem yöntemi, seçilen sorun hakkında bilgisi ve deneyimi olduğu düşünülen kişilerin tespit edilmesi ve seçilmesi işleminden oluşmaktadır (Akt., Palinkas ve ark., 2015). Bu uzmanlar, spor bilimcileri, sosyologlar, milli takım antrenörleri ve spor hekimlerinden oluşmaktadır. Konuyla ilgili ayrıntılı bir literatür taramasının ardından görüşmelerde kullanılacak sorular yarı yapılandırılmış olarak hazırlanmıştır. Görüşmeler öncesinde katılımcılara Bilgilendirilmiş Onam Formu onaylatılmıştır. Türkiye'nin yaz olimpiyatlarına ev sahipliği yapamamasının nedenleri ve çözüm önerileri ile ilgili olan sorular birebir ve yüz yüze yapılan görüşmelerde uzmanlara yöneltilmiştir. Katıımcıların onayı alınarak elektronik ortama kaydedilen bu 
görüşmeler, Ağustos 2018 ve Nisan 2019 arasında, İzmir ve İstanbul'da gerçekleştirilmiştir. Kaydedilen veriler transkript edildikten sonra araştırmacı tarafından tanımlayıcı içerik analizine tabi tutulmuştur. Transkriptler nitel araştırma yönteminde uzman olan iki ayrı akademisyene de inceletildikten sonra, analiz için gerekli kodlar ve temaların oluşturulması sağlanmıştır (Denzin ve Lincoln, 2000). Ortaya çıkan kodlar ve temalar sonucunda araştırmanın yazım aşamasına geçilmiştir. Çalışmada uzmanlardan bahsederken "U" harfi ve birer rakam kullanılıışır.

\section{Bulgular}

Görüşmelerden elde edilen veriler incelendiğinde, Türkiye'nin olimpiyatlara ev sahipliği yapamamasının nedenleri sekiz kategoriye ayrılmaktadır. Bunlar sırasıyla; spordaki başarısızık, sporun topluma yayılmaması, doping, siyasi ortam, yanlış şehir İstanbul, tesis-altyapı, ekonomi ve tanıtım olarak karşımıza çıkmaktadır.

\section{Spordaki Başarısızlık}

Uzmanların tamamına yakını, Türkiye'nin sporda başarısız bir ülke olduğunu, Türkiye'nin olimpiyatlardaki madalya sayısının az olmasının olimpiyatlara ev sahipliği yapamamasının önündeki en büyük engellerden biri olduğunu savunmaktadır. Örneğin, U9 ve U1 bu durumu şöyle dile getirmektedirler:

"Türkiye'nin elde ettiği madalya sayısına baktığımızda aslında birkaç branşta toplandığını görürüz. Yani işte, güreş, halter, uzak doğu sporları, bunun içerisinde bir tane 1948 olimpiyatlarında üç adım atlamada bronz madalyamız var. Yıllar sonra 2012'de alınan madalyalarımız var ama onları da geri verdik. Yani, böyle baktığımız zaman aslında bizim topu topu üç dört branşta faaliyet gösterdiğimiz, onun dışındaki bütün branşlarda hemen olmadığımız gibi bir durumla karşı karşıyayız. Ki bu, olimpiyat mantığıyla örtüşen bir durum arz etmiyor." U9

"Biz hala sporun önemini kavrayamamış ülkelerden bir tanesiyiz. Ya da kavrasak bile onun için bir şeyler yapmayı göze alamayan ülkelerden bir tanesiyiz. Olimpiyatlara katıldığımızı düşünün, kaç sporcumuzla başarıı olabiliriz? Sporcumuz yok bir kere. Bugün mesela Çin olimpiyatları yaptı, gene bir sürü madalya kazandı sporcularıyla. Yani önce sporu önemseyen bir ülke haline gelmeliyiz ki bize olimpiyat verilsin." U1

Yukarıdaki görüşler değerlendirilirken yalnızca yaz olimpiyatlarını değil, kış olimpiyatlarını, paralimpik oyunları ve uluslararası önem araz eden diğer yarışmaları da göz önünde bulundurmak gerekir. 


\section{Sporun Topluma Yayılmaması}

Uzmanlar, Türkiye'de beden eğitimi ve spor kültürünün topluma yayılmamış olmasının en önemli engeller arasında olduğunu söylemektedirler. Bu durum bir taraftan elit sporcu sayısını olumsuz etkilerken diğer taraftan seyircilerin ve sağlık sporu yapanların spora katılımını da beklenen seviyelerin çok altında tutmaktadır. Uzmanların görüşleri aşağıdaki gibidir:

"Bizim mesela bırakanlarla beraber bir buçuk milyon lisanslı futbolcumuz var, Almanya'da sekiz buçuk milyon. Aynı nüfustayız! Yani sporu yaygınlaştıramamışız.” U1

"Olimpik branşlarda ileriye gitmiş olmamız lazım. Öyle yüzde onuyla, yüzde yirmisiyle bu olimpik branşların başarı elde edilmesi ev sahibi ülke açısından dezavantaj. Yani spora çok istekli ve meraklı bir ülke olmadığımızı da, spor kültürünün yaygınlaşmadığını da gösteriyor." U7

"Olimpiyat Komitesi seyirci kapasitesine de bakar. Siz eğer bir atletizm müsabakasında iki üç tane seyirciyle koskoca Avrupa şampiyonasını, dünya şampiyonasını yapıyorsanız Türkiye'de, size bu organizasyonu vermezler... Olimpik kültürü sahiplenecek bir seyirci bizde yok. Bunu Erzurum 2011'de gördük." U5

Yukarıdaki açıklamaların beraberinde, kadınların ve engelli bireylerin beden eğitimi ve spor aktivitelerine katılımlarını da göz önünde bulundurmak gerekir.

\section{Doping}

Uzmanlar, yukarıdaki nedenlerin yanı sıra, son yıllarda gittikçe artan doping skandallarının da Türkiye'nin sicilini olumsuz etkilediğini düşünmektedirler. Örneğin, fair-play açısından ülkenin çok şey kaybettiğini söyleyen uzmanlar şunları eklemektedirler:

"Bizim için 2020 başvurusunda karşımıza çıkan en büyük sorun atletizm ve halterde yaşadığımız doping skandallarıydı." U10

"Doping yaygınlığı ülkeye zarar veriyor. Bu nedenle ahlaklı spor yapmanın altyapısının oluşturulması gerekiyor." U8

Katılımcılara göre, son yıllarda Türkiye'nin bu konudaki hassasiyeti ve mücadelesi artmış olsa da, dünya sporunun da en büyük sorunu olarak doping Türkiye sporuna hala büyük zararlar vermektedir. 


\section{Siyasi Ortam}

Katılımcılardan bazıları Türkiye'nin siyasi ve dini yapısının olimpiyatları alamamasının nedenleri arasında yer alabileceğini, bir İslam ülkesi olmasının adaylığını olumsuz etkilemiş olabileceğini savunmaktadırlar.

"Ülkenin siyasi durumu da zannederim burada etkili oluyor. Yani dışarıdan bakıyorlar, mesela atletizmde buna örnek olarak vereyim. Üç yıl üst üste Mersin'de Avrupa kulüpler şampiyonası yapılacaktı, öyle almış federasyon, birincisi ikincisi yapıldı, üçüncüsü birdenbire bizden alındı... Bazı ülkeler güvenlik nedeniyle gelmek istememiş." U2

Seçmelerde bir İslam ülkesi olduğu için negatif ayrımcılığa maruz kalmış olabileceğini söyleyenlerin aksine, U9, bu işin İslam ülkesi olmayla alakası olmadığını, asıl önemli şeyin madalya sayısı olduğunu belirtmektedir. Bu noktada tüm İslam ülkelerinin olimpiyat madalya sayısına bakıldığında, bir İtalya'nın madalya sayısı kadar bile olmadığını söylemektedir. Örneğin, nüfusu Türkiye'den daha az olan İtalya'nın 2016 itibariyle olimpiyat madalya sayısı 577 iken, Türkiye'nin madalyasının 93 olması U9'un söylediklerini dikkate değer kılmaktadır.

\section{Yanlış Şehir İstanbul}

Katılımcılardan bazıları İstanbul'un yanlış bir seçim olduğunu, bunun yerine başka bir şehir aday gösterilmesinin daha uygun olacağını düşünmektedir. İstanbul'un trafiğinin ve yoğun nüfusunun olimpiyatların düzenlenmesini zorlaştıracağını savunan görüşmeciler şunları belirtmektedir:

“Ulaşım sorunu bu tür organizasyonları uygulayacak ülkeler için önemli kriterlerden bir tanesi. Çünkü Olimpiyat Oyunları bildiğiniz gibi canlı yayınlanan ve spor yayıncılığı açısından da önemli bir yere gelmiş bir organizasyon. Dolayısıyla bu ulaşım kısmı canlı yayıncılık acısından çok önemli kılıyor. Örneğin yüz metre koşusu için belirlenen saat 9.00, sporcunun oraya gelmesini eğer sağlayamıyorsanız, 9.00'daki bir yarışın 9.15’te, 9.20'de yayınlanması spor yayıncılığı açısından büyük sorun..." U10 “İstanbul'un trafiğiyle baş etmek mümkün değil. Siz şimdi İstanbul'a olimpiyatları aldığınızda, eğer iyi bir yere olimpiyat köyü kuramamışsanız, tesislerinizi de birbirlerine yakın yerlerde kurmadıysanız insanlar sadece bir spor dalını seyretmeyecekler, hepsi ile ilgilenecekler, sağa sola gidecekler..." U5 


\section{Tesis-Altyapı}

İstanbul ve genel olarak Türkiye'deki spor tesis ve altyapı sorunlarının engeller arasında olduğunu söyleyen bazı katılımcılar, bu konuda atılan kısa vadeli adımların işe yaramayacağını savunmaktadırlar.

"Biz hep olimpiyatları almak isteriz ve gideriz. Ama elimizde hiçbir zaman bir hazırlığımız yoktur. En son Brezilya'da yapılan toplantıya gidildiğinde elimizde bir sürü tenis kortu vardı, hepsi, deniz doldurularak yapılacaktı. Haydarpaşa limanının oralarında yapılacaktı. Şu anda olimpik spor tesisimiz olarak futbol ve atletizm sahası var. Onun da bulunduğu konum, rüzgârlara son derece açık... Yani hiçbir şekilde bir hazırlığımız yok. Ve insanlar bunu görüyorlar. " U5

"Ülkede çok kısa erimli çalışmalar yapılıyor. Bir takım altyapı çalışmaları olmadık yerlere yapılıyor. Ülkede olimpiyat gibi büyük bir organizasyonu kaldıracak altyapı olduğunu düşünmüyorum. Ya da İstanbul gibi büyük bir metropolde bunu nasıl kaldıracaksın, trafik düzenlemesini nasıl yapacaksın, hani, altyapıyı ulaşılabilir nasıl kılacaksın? U4

\section{Ekonomi}

Ülke ekonomisinin de engeller arasında olduğunu söyleyen bazı katılımcılar Türkiye'nin Uluslararası Olimpiyat Komitesi'ni bu konuda kaygılandırmış olabileceğini düşünmektedirler.

"Ülke ekonomisinin yapılacak işlerin kalitesinin belirlenmesi, yani gelecek sporcuya her türlü imkânın sağlanması için iyi bir ekonomik temel olmalı." U8

“ístikrarsız bir ekonominin, güvenlik sorunlarının eşlik ettiği bazı sorunlar olabileceğini düşünüyorum. Türkiye büyük bir ülke, tabi buna bağlı olarak kendi iç sorunlarını tam anlamıyla çözememiş oluşunun getirdiği sıkıntılar da etkili olabilir." U3

\section{Tanıtım}

Bazı katılımcılar, Türkiye'nin spor dünyasındaki tanıtımının yetersiz olduğunu düşünmektedir. Bu elbette uluslararası başarıyla artabilir, ancak, katılımcılar 2020 için hazırlanan tanıtım videosunun bile Türkiye'yi olumsuz gösterdiğini iddia etmektedirler.

"Tanıtım filmi bile bizim bu işten ne kadar uzak olduğumuzu gösteriyor. Bir Japonların tanıtım filmiyle Türklerin tanıtım filmi arasında çok fark vardı. Sunum çok kötüydü. Bir de, Türkiye'ninkinde dini özellikler çok ön plandaydı. Hâlbuki ki bu bir spor organizasyonu... Spordan izler yoktu ve bu da adamları korkutuyor tabi ki." U11 
“Çok önemli bir tanıtım etkinliği gerçekleştirmeniz gerekir. Ki bu da sadece biz çok büyük bir ülkeyiz demekle olmaz. Yani bunun arkasında sizin çok iyi bir PR çalışması yapmanız lazım." U9

U6'ya göre ise ülkemiz bu olimpiyatları rahatlıkla düzenleyebilir. Ona göre oyunlar bizden daha zayıf ülkelere de verildi.

“Kıl payı Tokyo’ya kaptırdıysak, demek ki gücümüz var (2020 için). Demek ki kriterlerimiz tutuyor. Dış kamuoyuna yönelik çalışmalarla bize karşı olan bakış açılarını değiştirmeliyiz" U6

\section{Neler Yapılmalı?}

Uzmanlardan Türkiye'nin olimpiyatlara ev sahipliği yapamamasının nedenlerine dair yanıtlar alındıktan sonra; kendilerine, Türkiye'nin bir olimpiyat ülkesi olabilmesi ve olimpiyat ev sahipliğini kazanabilmesi ile ilgili sorular yöneltilmiştir. Ortaya çıkan kategoriler şöyle sıralanmaktadır: Belediyeler, federasyonlar ve devlet etkin olmalı; spor topluma yayılmalı; bir spor sistemi kurulmalı; spordan sorumlu merkezlerde liyakat olmalı; şehir değiştirilmeli; Türkiye sporundan doping silinmeli.

\section{Belediyeler, federasyonlar ve devlet etkin olmalı}

Katılımcıların tamamına yakını, yerel yönetimlerin, federasyonların, Milli Olimpiyat Komitesi'nin ve Gençlik ve Spor Bakanlığı'nın daha etkin roller üstlenerek sporda başarıyı arttıracak çalışmalar yapması gerektiğini düşünmektedirler. Örneğin, U10 görüşlerini şöyle dile getirmektedir:

"Yetişmiş personel veya sporcularımızı çok iyi kullanmıyoruz. Bu bireyler uluslararası federasyonların ilgili kurullarına mutlaka girmeliler. Örneğin dünya yüzme federasyonuna baktığımızda içerisinde yaklaşık un üç, on dört tane kurul var. Ve kurulların her birinin içerisinde de yaklaşık onar kişi var. Bu da yüz kırık kişi eder. Türkiye'den sadece üç kişi var! Genel olarak baktığımızda olimpiyat adaylığını değerlendiren kurulların içerisinde de uluslararası federasyonların temsilcileri oluyor, yani birbirinden kopuk değil bunlar." U10

U9'a göre ise, sanata yatırım yapan burjuvazinin de elini taşın altına koyarak, spora destek vermesi gerekmektedir. Ülkeler ve kurumlar arası siyaset bu işte çok belirleyici olduğunu savunan U8, devletin kurumlarının uluslararası görüşmeleri yürütmesi gerektiğini belirtmektedir.

"Olimpik eğitim alanında yapılacak programlar üniversitelerde bu alanda (olimpik eğitim, olimpik değerler, olimpizm vb.) çalışmış akademisyenler ve eğitim programı 
konusunda uzman kişiler tarafından hazırlanacağından üniversitelerin rolü önemli. Örneğin; Pekin olimpiyatları hazırlık aşaması üniversitelerin rolünün ortaya konulması bakımından çok büyük bir örnektir." U12

Türkiye'de çok büyük organizasyonlar yeterince yapılmadığından olimpiyat gibi büyük bir organizasyonu düzenlemek konusunda yeterli tecrübeye sahip olmadığını söyleyen bazı katılımcılar, olimpiyat komitesinin bunu dikkate aldığını düşünmektedirler.

\section{Spor topluma yayılmalı}

Sporun Türkiye'deki eğitim sisteminin bir parçası olması ve toplumun geneline yayılması gerektiğini söyleyen katıımcılar, yarışma sporundaki başarının yanı sıra toplumdaki spor kültürünün gelişiminin önemli olduğu görüşündeler. Dolayısıyla bir spor ülkesi olmadan, olimpiyatları almanın pek mümkün görünmediğini düşünmektedirler.

Örneğin, Türkiye Milli Olimpiyat Komitesi'nin (TMOK) topluma sporun yaymada zayıf kaldığını, sadece İstanbul'a ağırlık verdiğini ve bu durumun değişmesi gerektiğini söyleyen U10, ilkokul çağındaki çocukların aktivitelerinin de çok kısıtlandığını, tesisler yapılsa bile çocukların bu tesislerde spor yapacak vakitlerinin kalmadığını vurgulamaktadır. U9 ise, süreklilik arz eden kampanyalarla kadınların spora katııımının arttırılmasının, sivil toplum örgütlerinin ve kulüplerin spor kültürünün yayılmasında sıkı çalışmasının ve bu uzun vadeli süreçte iyi sporcuların rol model olarak görev almasının önemini dile getirmektedir. Benzer görüşler aşağıdaki şekilde ifade edilmektedir.

"Sporun gelişmesi büyük büyük statlarla olmaz. Önce mahallelere inmeniz lazım. Siz mahallelerde insanlara spor yapacakları olanakları geliştiremiyorsanız, büyük statlar sizin hiç işinize yaramaz. Kocaman bir stat yapacağınıza on tane mahalleye on tane spor salonu yaparsınız en az. Yüzme havuzu yaparsınız. Atletizm pisti yaparsınız. Parkurlar yaparsınız. Biz bunların yerine koca arenalarla uğraşıyoruz. Ama o arenaları kim kullanıyor, kaç gün kullanıyor? Bir de orada kaç kişi spor yapabiliyor, sadece seyirci girip seyrediyor ve çıkıyor." U5

"Futbol gibi büyük bir endüstri var her şeye egemen olan ve neredeyse spor politikalarının büyük çoğunluğu bunlar üzerinden yürüyor. Şimdi olimpik hareketin içinde olabileceği bir ülkede çocuklara ve farklı branşlara yayılan ve hani o felsefe çerçevesinde her çocuğu spora katmaya elverişli bir sistem kurulması gerekiyor." U4 


\section{Bir spor sistemi kurulmalı}

Katılımcılar, tüm yapıyı birleştiren bir stratejinin ve bu stratejiyi de uygulayacak bir merkezin kurulması gerektiğini vurgulamaktadırlar. Bazı katılımcılar, sporda yeteneğin keşfedilmesi ve yetiştirilmesi için yerelden genele yayılan, test ve tespit merkezlerinin kurulması gerektiğini belirtmektedirler. Görüşlerin bazıları şöyle dile getirilmiştir:

"Merkezi olarak sporcuların performansını ölçen, yeteneklerini tespit eden, ya da performans sporcularımızın gelişimini takip eden, sağlıklarını takip eden... bir merkez kurulmalı. Bu ölçümler sonucunda yabancılarla kartlaştırmalar da yapılabilir. Dünya çapındaki sporcuların profilleri vardır." U1

"Okuldaki tesisleşmenin artması, oradaki beden eğitimi öğretmenlerinin sayısının artması, onların kurulacak olan stratejik yapının, sistemin bir parçası haline getirilmesi, çocukları takip eden ve merkezden takip edilen sistemlerin kurulması ve bunları yaparken de çocukların rekreatif zamanını da düzenleyen uzmanlar olarak da yer almaları gerekiyor beden eğitimi öğretmenlerinin." U4

\section{Spordan sorumlu merkezlerde liyakat}

Spordan sorumlu merkezlerde sporcuların, antrenörlerin ve yöneticilerin seçilmesinde mutlaka liyakate bakılması gerektiğinin üzerinde duran bazı katılımcılar, böylece başarının da artacağını savunmaktadırlar. U5 ve U7'nin görüşleri şöyledir: "TMOK bu işte başı çekmeli. Tabi olimpiyat komitesinin şu andaki yapısıyla ilgili de eleştiride bulunmak lazım. Her önüne gelen olimpiyat komitesi üyesi olabilir mi? Olmamalı. Sporda gerçekten bu konuda deneyimleri olan insanlar oraya seçilmeli. Ama biz görüyoruz ki şu anda iş başındaki insanların çoğu sporla alakalı insanlar değiller." U5

"Devletin memurlarının antrenör eğitiminden elini çekmesi lazım. Fizyoterapistlerin antrenörlük gibi bir branşta görev yapması kararı çok yanlış bir karardı mesela." U7

\section{Şehir değiştirilmeli}

Uzmanlardan bazıları, Türkiye'nin İstanbul konusundaki ısrarından vaz geçmesi gerektiğini çünkü İstanbul'un olimpiyat adayı bir şehir olarak birçok açıdan uygun olmadığını dile getirmektedirler.

“Bence İstanbul'dan vazgeçilmeli artık. Çünkü Istanbul, evet, imkânları açısından bakarsanız Türkiye'nin ticaret merkezi de olduğu için... İstanbul dışında böyle bir organizasyonu düzenleyeceğimiz yerin altyapısının kurmadık." U10 
U10 ve U11, İstanbul yerine İzmir veya Antalya gibi şehirlerin seçilmesinin bu organizasyonları düzenlemek açısından daha doğru olacağını düşünmektedirler. Özellikle Antalya'nın bir turizm şehri olarak ulaşım ve yatak kapasitesi konusunda büyük avantajı olduğunu savunmaktadırlar.

\section{Türkiye sporundan doping silinmeli}

Yukarıda da değinildiği üzere, uzmanların en büyük kaygılarından biri de Türkiye'nin doping skandallarıyla anılmaya başlamasıdır. Bu nedenle görüşmelerden elde edilen ortak görüş doping konusunda Türkiye'nin ciddi adımlar atarak sicilini temize çıkarması gerektiğidir.

\section{Tartışma ve sonuç}

Türkiye gibi spor kültürünün zayıf olduğu ülkelerde olimpiyatlara ev sahipliği yapmak ülke sporuna önemli bir katkı sağlayabilir. Bu nedenle uzmanların yukarıdaki görüşleri büyük önem arz etmektedir. İlgili literatür incelendiğinde, bu görüşleri destekleyen yazarlara rastlanmaktadır. Örneğin, bazı yazarlar, Türkiye sporunda son dönemlerde doping olaylarının gündeme gelmesinin (Görkemli ve ark., 2014; Wintermantel ve ark., 2016) ve Türkiye'nin doping kullanımında Rusya ile Hindistan'ın arkasından üçüncü sırada olmasının olumsuz bir imaj oluşturduğunu (Karar Gazetesi, 12.05.2016) düşünmektedirler. İstanbul'un yanlış şehir olduğunu savunan yazarlar ise, küçük bir coğrafi alana sahip olmasına rağmen İstanbul'un giderek artan nüfusunun; hiçbir şekilde çözülemeyen ve her geçen gün daha da yoğunlaşan trafiğinin (Feddersen ve ark., 2008; Özbey, 2013; Yalçın, 2014) kentsel dönüşümün neo-liberal politikalar çerçevesinde işleyişi ve İstanbul'un yeşil alanlarının yok olmasıyla hızla büyüyen betonlaşmanın (Ergun ve Koçancı, 2017) ve son başvuruda olimpiyat yerleşim planlamasındaki konseptin kent merkezli değil de yaygın bir şekilde haritalanmasının (Yalçın, 2014) İstanbul'dan vazgeçmek için yeterli nedenler olduğunu savunmaktadırlar. Buna ek olarak, savaş sebebiyle Türkiye'ye göçen Suriyeli mültecilerin büyük bir çoğunluğunun İstanbul'da bulunmasını (Torun ve ark., 2018) da nedenler arasında saymaktadırlar. Tesis ve altyapı ile ilgili sorunlara değinen bazı yazarlar ise, olimpiyat adaylık sürecinde inşa edilen Olimpiyat Stadyumu çevresindeki Ayazma ve Yarımburgaz mahallelerinin yoksullaş(tırıl)masının (Yalçın, 2014) ve son başvuruda önerilen 38 tesisin sadece 11 tanesinin bitmiş olmasının (Özbey, 2013; Yalçın, 2014) IOC'nin seçici kurullarını etkilediğini düşünmektedirler. Kimilerine göre ise, ev sahipliği seçim süreçlerinde ülke 
genelindeki siyasi iklimde toplumsal barış ortamının olmaması ve insan hakları ihlallerinin sıklığı (Görkemli ve ark., 2014) da adaylığı olumsuz etkilemiştir.

Çalışmamızda Türkiye'nin İslam ülkesi olmasıyla ilgili uzmanların görüşleri birbirleriyle çelişmektedir. Örneğin U9, diğer bazı katılımcıların aksine IOC'nin İslam ülkesi olup olmadığımıza değil spordaki başarımıza göre değerlendirme yaptığını belirtmektedir. Aynı konuda dönemin Başbakanı Recep Tayyip Erdoğan, Müslüman ülke olmanın da IOC'nin kararını olumsuz etkilediğini ima etmekteydi:

“Londra 3, Madrid 2 kez yaptı. Tokyo 2 kez yaptı. Bu ülkeler 2-3 kez yapmışken Türkiye 5 kez finale kadar gelmiş ve hâlâ böyle bir olimpiyata ev sahipliği yapmayı vermediler. Halkın büyük çoğunluğu Müslüman olan bir ülkede bugüne kadar bir olimpiyat düzenlenmedi. Sorarlar insana: Ne için?" (Habertürk, 30.07.2012).

Buna karşın, eski TMOK Başkanı Togay Bayatlı ile TMOK Yönetim Kurulu Üyesi Neşe Gündoğan IOC'nin kararını bir İslam ülkesi olmanın etkilemediğini savunmuşlardır (Habertürk, 30.07.2012).

Uzman katılımcıların en önemli vurgusu spora katılım üzerineydi. Bu açıdan, Türkiye'nin, özellikle kitlelere spor imkânlarını ulaştırması ve daha fazla engelli bireyin, kadının ve çocuğun spora katılımını sağlaması gerekmektedir. Böylece, ülkede spor kültürü gelişirken uluslararası düzeyde de başarılar artacaktır. Uzmanların önerilerini özetlemek gerekirse; devletin ilgili tüm kurumları spora daha organize olarak yaklaşmalı ve uzun vadeli planlar yapmalı; özellikle altyapı ve tesislerin oluşturulmasında toplumun yararı göz önünde bulundurulmalı; spor toplumun geneline yayılmalı; engelli bireylerin ve kadınların katılımı arttırılmalı; bir spor sistemi oluşturulmalı; sporcuları seçecek ve yetiştirecek merkezler kurulmalı; spordan sorumlu bu merkezlerde liyakate önem verilmeli; İstanbul yerine örneğin Antalya veya İzmir gibi şehirler aday gösterilmeli; Türkiye sporundan dopingin silinmesi için daha güçlü bir mücadele verilmeli; uluslararası spor federasyonlarına ve spor kuruluşlarına Türkiye'den antrenörlerin, hakemlerin ve spor yöneticilerinin girebilmesi için kapsamlı bir eğitim sistemi oluşturulmalı; Türkiye'nin sporunu tanıtacak videolar daha özenli hazırlanmalı ve bu videolar özellikle spor odaklı olmalı ve federasyonlar uluslararası yarışmaları Türkiye'ye getirmek için daha çok çalışmalıdır. Sonuç olarak, olimpiyatlar gibi büyük organizasyonlara ev sahipliği yapabilme yolunda Türkiye'nin atacağı uzun erimli adımların, ülkedeki spor kültürünün gelişimine katkıda bulunacağı ve uluslararası yarışmalarda başarısını 
arttıracağı öngörülmektedir. Böylece, IOC'nin seçici kurullarının Türkiye'nin adaylık süreçleriyle ilgili yapacağı değerlendirmelerde Türkiye'nin söz konusu kültürel gelişimi ve başarıları önemli bir rol oynayacaktır. Dahası, bu gelişim ve başarı, Türkiye'ye karşı var olduğu düşünülen önyargıların kırılmasına da vesile olacaktır.

\section{Kaynaklar}

Ashworth, G., \& Kavaratzis, M. (2009). Beyond the logo: Brand management for cities. Journal of Brand Management. 16(8), 520-531.

Aslan, B.G., Ankaya, F.Ü. ve Balık, G. (2019). Olimpiyat köyleri, ülkeye katkıları, dünyadan Türkiye'den örnekler. Ulusal Çevre Bilimleri Araştırma Dergisi. 2(1):1-10.

Denzin, N. ve Lincoln Y. (2000). Handbook of Qualitative Research. 3rd ed. Thousand Oaks, CA: Sage.

Ergun, C. ve Koçancı, M. (2017). Yoksulluk ve kentsel mekan üzerine birkaç not... Toplum ve Demokrasi Dergisi. 11(24);201-28.

Feddersen, A., Maennig, W. ve Zimmermann, P. (2008). The empirics of key factors in the success of bids for olympic games. Rev Econ Polit. 118(2);171-87.

Görkemli, H., Matır, L., Çelik, C., ve Seki, Ö. (2014). Kent imajı açısından olimpiyatlar: selçuk üniversitesi öğrencilerine yönelik bir uygulama. Gümüşhane Üniversitesi İletişim Fakültesi Elektronik Dergisi. 2(3):178-96.

Kavanoz, S. E. (2017). Olimpiyat oyunlarinin ev sahibi kent üzerindeki etkileri. Uludağ Üniversitesi İktisadi ve İdari Bilimler Fakültesi Dergisi. 36(2), 57-73.

Leopkey, B. ve Parent, M.M. ( 2009). Risk management issues in large-scale sporting events: a stakeholder perspective. European Sport Management Quarterly. 9(2);187-208.

Liao, H. ve Pitts, A. (2006). A brief historical review of olympic urbanization. Int J Hist Sport. 23(7):1232-52.

Özbey, S. (2013). The fifth attempt to host the olympiad; istanbul's bid for 2020 summer games. Int J of Academic Research. 5(3);407-19.

Palinkas, L.A., Horwitz, S.M., Green, C.A., et al. (2015). Purposeful sampling for qualitative data collection and analysis in mixed method implementation research. Adm Policy Ment Health. 42(5):533-44.

Patton, M.Q. (2002). Qualitative Research and Evaluation Methods. 3rd ed. Thousand Oaks, CA: Sage. 
Slater, A., and Tiggemann, M. (2010). "Uncool to do sport": A focus group study of adolescent girls' reasons for withdrawing from physical activity. Psychology of sport and exercise. 11(6), 619-626.

Torun, P., Karaaslan, M.M., Sandıklı, B., et al. (2018). Health and health care access for syrian refugees living in istanbul. Int J of Public Health. 63(5);601-8.

Uysal, Ü.E. (2014). Büyük etkinlikler: kente ve kent mekânına etkileri. J of Faculty of Political Science. 51:163-79.

Ünlü, H. (2015). Olimpiyat oyunlarına adaylık ve ev sahipliği sürecinde olimpik eğitimin yaygınlaşmasında üniversitelerin rolü. Abant İzzet Baysal Üniversitesi, Sosyal Bilimler Enstitüsü, Spor Yöneticiliği Anabilim Dalı, Spor Yöneticiliği Bilim Dalı Yüksek Lisans Tezi. Abant İzzet Baysal Üniversitesi.

Wintermantel, J., Wachsmuth, N. ve Schmidt, W. (2016). Doping cases among elite athletes from 2000 to 2013. Dtsch Z Sportmed. 67:263-9.

Yalçın, F.A. (2014). Ev sahibi kentler ile olimpiyat oyunları'nın etkileşimi ve adaylık sürecindeki istanbul değerlendirmesi. İstanbul Teknik Üniversitesi, Fen Bilimleri Enstitüsü, Mimarlık Bölümü, Kentsel Tasarım Anabilim Dalı Yüksek Lisans Tezi. İstanbul Teknik Üniversitesi.

Zhang, L., \& Zhao, S. X. (2009). City branding and the Olympic effect: A case study of Beijing. Cities. 26(5), 245-254.

İnternet Kaynakları: Habertürk.https://www.haberturk.com/polemik/haber/763050erdogan-sorarlar insana-ne-icin\#Erişim Tarihi: 2 Mayıs 2019.

Karar Gazetesi. https://www.karar.com/spor-haberleri/turkiye-en-cok-dopingkullanan-sporcular-siralamasinda-ucuncu-sirada-yer-aldi-120517. Erişim Tarihi: 5 Mayıs 2019. 